\title{
A Diagnostic Criteria for Temporomandibular Disorders (DC/TMD) magyar nyelvú változatának létrehozása
}

\author{
DR. SOMOSKÖVI ISTVÁN, DR. RADÁCSI ANDREA, DR. NAGY ÁKOS KÁROLY, DR. RADNAI MÁRTA
}

\begin{abstract}
A temporomandibuláris rendellenességek (Temporomandibular Disorders, TMD) a fogorvostudomány komoly kihívást jelentő, magas prevalenciát mutató betegségcsoportja. A szakemberek között a mai napig sincs teljes egyetértés a TMD etiológiája, klasszifikációja és kezelése kapcsán, ugyanakkor a páciensek alapvető érdeke, hogy betegségükkel kapcsolatban valid kutatási eredmények szülessenek. A TMD diagnosztikája jelentős fejlődésen ment keresztül az elmúlt évtizedekben. A Diagnostic Criteria for Temporomandibular Disorders (DC/TMD) egy 2014-ben publikált, kutatási és klinikai felhasználásra egyaránt alkalmas rendszer, mely megfelel a bizonyítékokon alapuló orvoslás kritériumainak. A PTE Fogászati és Szájsebészeti Klinikán felállt kutatócsoport elkészítette a DC/TMD magyar nyelvű változatát, ezzel lehetővé téve a hazai szakemberek számára, hogy egy nemzetközileg elfogadott diagnosztikus eszközt használhassanak. A cikk bemutatja a DC/TMD-t és részletezi a munkacsoportunk által végzett fordítási-adaptációs folyamatot.
\end{abstract}

Kulcsszó: DC/TMD, temporomandibuláris rendellenesség, diagnózis, krónikus fájdalom

\section{Bevezetés}

A temporomandibuláris rendellenességek (Temporomandibular Disorders, TMD) a fogorvostudomány komoly kihívást jelentő betegségcsoportja. A jelenleg leginkább elfogadott álláspont szerint a TMD heterogén, multifaktoriális betegségcsoport, melynek egyes formái hasonló tünetekkel járnak. Jellegzetes a preaurikuláris területen, a rágóizomzatban, illetve az arc különböző részein jelentkező fájdalom, a temporomandibuláris ízületben és rágóizomzatban kialakuló nyomásérzékenység, a korlátozott, illetve rendellenes állkapocsmozgások és az ízületi hangjelenségek.

A TMD kialakulásában szerepet játszó etiológiai tényezők között okklúziós eltéréseket, az állcsontok ortopédiai instabilitását, bruxizmust, fogszabályozó kezelést, makro- és mikrotraumát, ízületi lazaságot, rossz általános egészségi állapotot, exogén ösztrogénbevitelt említ a szakirodalom. Egyes pszichoszociális faktorok (stressz, szorongás, depresszió) szintén vezethetnek a betegség kialakulásához [9].

A nemzetközi szakirodalom eltérő adatokat közöl a TMD prevalenciáját illetően. Schiffman és munkatársai 5-12\% közé teszik a gyakoriságot, és megállapítják, hogy ezzel a krónikus hátfájdalmat követő második leggyakoribb muszkulo-szkeletális betegség és a leggyakoribb, nem fog eredetú betegség, ami etiológiai faktorként az orofaciális fájdalom hátterében állhat [8]. Az egyes tünetek előfordulási gyakoriságában jelentősebb eltérésekről számolnak be az irodalmi források (az intrakapszuláris elváltozások esetén 16\%, az ízületi hangjelenség esetében 14\% [10], míg az izom és ízületi eredetű fájdalomnál $6,6 \%$ [4]).

A TMD esetében nagy jelentőséggel bír a fájdalom egyénre gyakorolt hatásának felismerése (pszichés állapot, életminőséget befolyásoló hatás, szakrendeléseken való megjelenés gyakorisága). Ebben a tekintetben a TMD hasonlóságot mutat más, krónikus fájdalommal járó betegségekkel, mint a krónikus hátfájdalom, fejfájás vagy a fibromyalgia [2].

Az egységes nómenklatúra hiánya, valamint az egymásnak gyakran ellentmondó nézetek a betegség etiológiáját, diagnosztikáját és terápiáját illetően nagymértékben megnehezítik mind a kutató, mind a klinikus munkáját. A TMD különböző formáiban szenvedő betegeknek ugyanakkor elemi érdeke, hogy megbízható, általánosan elfogadott kutatási eredmények szülessenek a betegségükkel kapcsolatban. Ennek pedig alapvető feltétele, hogy olyan diagnosztikus rendszert használjunk, amely egyrészt igyekszik megfelelni a bizonyítékon alapuló orvoslás kritériumainak, másrészt egységesen elfogadott. Amennyiben ezek a feltételek teljesülnek, akkor lehetőség van az egyes országokban, illetve különböző nyelvterületeken kapott eredmények közvetlen összehasonlítására és azokból helytálló következtetések levonására.

A TMD diagnosztika korai szakaszában a mechanikus szemlélet uralkodott, amikor a betegség kialakulásáért kizárólag az állkapocsízület (azon belül is elsősorban a diszkusz) patológiás elváltozásait tették felelőssé 
(Annandale, 1887). Costen elmélete (1934) szerint a különböző malokklúziók következtében fellépő erőhatások okkluzális instabilitást eredményeznek és ezek okolhatók a TMD-ben jelentkező fájdalomért. Ez a modell évtizedeken keresztül uralta a TMD diagnosztikát és terápiás elveket, és a mai napig is jelen van a köztudatban annak ellenére, hogy a helyességét egyértelmúen igazoló tudományos bizonyítékok nem állnak rendelkezésre [7].

Az egyik legelterjedtebben használt diagnosztikus eszköz az 1974-ben publikált Helkimo-féle diszfunkciós index [1]. Ez anamnesztikus, diszfunkciós és okklúziós elemekből épül fel. Az anamnesztikus index (Ai) a páciens által jelzett szubjektív panaszok alapján sorolja be a rendellenességet három különböző fokú diszfunkciós csoportba (Ai-0, Ai-I, Ai-II). A diszfunkciós index (Di) a mandibula mozgástartománya, az ízületi funkciók korlátozottsága és a rágóizmokban, illetve az ízületben jelentkező fájdalom vizsgálata alapján, pontozásos rendszerben alkot diagnózist (Di-0, Di-I, Di-II, Di-III). Az okklúziós index (Oi) szintén pontozással értékeli a beteg okklúziós vagy artikulációs eltérésének mértékét (Oi-0, Oi-I, Oi-II).

Az 1980-as évektől kezdve a TMD lehetséges etiológiai tényezőinek kutatásában megjelenik a pszichoszomatikus háttér. Eszerint egyes, gyakori mentális rendellenességek, mint a szorongás vagy depresszió állhatnak az objektív módon nem magyarázható klinikai tünetek (például a krónikus fájdalom) mögött. Azonban az etiológiai faktorok szerepének tudományos bizonyítása ezen a területen is nehézségekbe ütközik.

Az említett problémák arra késztették a szakembereket, hogy a nehezen bizonyítható etiológiai megközelítés helyett inkább egy bizonyítékokon alapuló, leíró diagnosztikai rendszert hozzanak létre. Az 1992-ben publikált RDC/TMD (Research Diagnostic Criteria for Temporomandibular Disorders) - ahogy arra az elnevezés is utal - elsősorban kutatási célokra alkalmas. Az RDC/TMD újdonságot jelentett abból a szempontból, hogy a diagnózist két tengely mentén állította fel. Az egyik tengely fizikális diagnózist szolgáltatott, a másik pedig a páciens pszicho-szociális profiljára vonatkozóan adott információt [3]. Az RDC/TMD-ben pontos definíciók és specifikációk alapján történik a klinikai betegvizsgálat és az eredmények értékelése is.

A 2010-es években a folyamatos kutató-fejlesztő munka és az RDC/TMD diagnosztikus lehetőségeinek finomítása által jött létre a DC/TMD (Diagnostic Criteria for Temporomandibular Disorders, 2014) [8]. A DC/TMD megalkotóinak célja egy olyan diagnosztikus eszköz létrehozása volt, amely kutatási és klinikai használatra egyaránt alkalmas. Továbbá kiemelt cél volt, hogy a DC/TMD standardizált legyen, tehát reprodukálható módon, megbízhatóan gyüjtsön adatokat és szolgáltasson diagnózist.

Megállapítható, hogy amíg a kezdeti időszakban a TMD diagnózis kifejezetten az állkapocsízület elváltozásaira vonatkozott, mára ez a fogalom jelentősen kiszélese- dett és ezért „temporomandibuláris ízületi rendellenesség” (vagy „diszfunkció”) helyett ma már relevánsabb a „temporomandibuláris rendellenesség” kifejezés használata. Ugyanakkor az irodalomban találkozhatunk a „kraniomandibuláris rendellenesség”, illetve „kraniomandibuláris diszfunkció" elnevezésekkel is. Ezzel összhangban a mai diagnosztikus rendszerekkel szemben is elvárás, hogy ne csak az intrakapszuláris elváltozást, hanem a teljes tünetegyüttest és annak a beteg életére gyakorolt hatását is képesek legyenek leírni.

\section{Vizsgálati anyag és módszer}

\section{A DC/TMD felépítése}

A teljes $\mathrm{DC} / \mathrm{TMD}$ „csomag” 3 nagy részből áll: a diagnosztikus eszközökből (Assessment Instruments), a részletes betegvizsgálati leírásból (Clinical Examination Protocol) és a kérdőívek kiértékelését segítő útmutatóból (Scoring Manual for Self-report Instruments). A diagnosztikus eszközöket két további csoportra lehet bontani: a klinikai vizsgálat és a páciens által kitöltendő kérdőívek (12 db) (1. ábra).

A DC/TMD (az RDC/TMD-hez hasonlóan) két tengely mentén állít fel diagnózist. Az I. tengely fizikális diagnózist szolgáltat, melynek két komponense van: a fájdalom, illetve fejfájás típusának diagnózisa (pl. kisugárzó myofasciális fájdalom) és az intrakapszuláris elváltozás diagnózisa (pl. diszkusz diszlokáció redukcióval). Ezekhez a klinikai vizsgálat eredményeinek, valamint a páciens által kitöltött Tüneti kérdőív kérdéseire adott válaszok egy folyamatábrába (algoritmusba) történő behelyettesítésével jutunk el (1. és 2. kép). A II. tengely diagnózisai a TMD páciens fájdalmának az életminőségre gyakorolt hatását, a szájüregi funkciók változását, valamint a páciens pszichológiai státuszát mérik fel. A II. tengely diagnózisokhoz az egyes kérdőívek pontozásos értékelésével juthatunk (így jellemezhetjük például a depreszszió, szorongás vagy a rágófunkciók beszúkülésének mértékét).

\section{A fordítás és kulturális adaptáció menete}

A DC/TMD különböző nyelvű változatainak megalkotását egy nemzetközi szervezet, az INfORM (International Network for Orofacial Pain and Related Disorders Methodology) koordinálja és felügyeli, amely ezáltal minőségbiztosítási szerepet is ellát. Az INfORM által közzétett útmutató (Guidelines for Translation and Cultural Equivalency of Instruments) lépésről lépésre vezeti a fordítást végző csoportot annak érdekében, hogy az újonnan létrehozott egyes nyelvi változatok ekvivalensnek legyenek tekinthetők [5]. Ez teszi lehetővé, hogy a különböző nyelvi és kulturális környezetben a diagnosztikus adatok gyújtése egyformán és megbízható módon történjen, és az így nyert adatok általános érvényűek és összehasonlíthatók legyenek. A fordítási- 


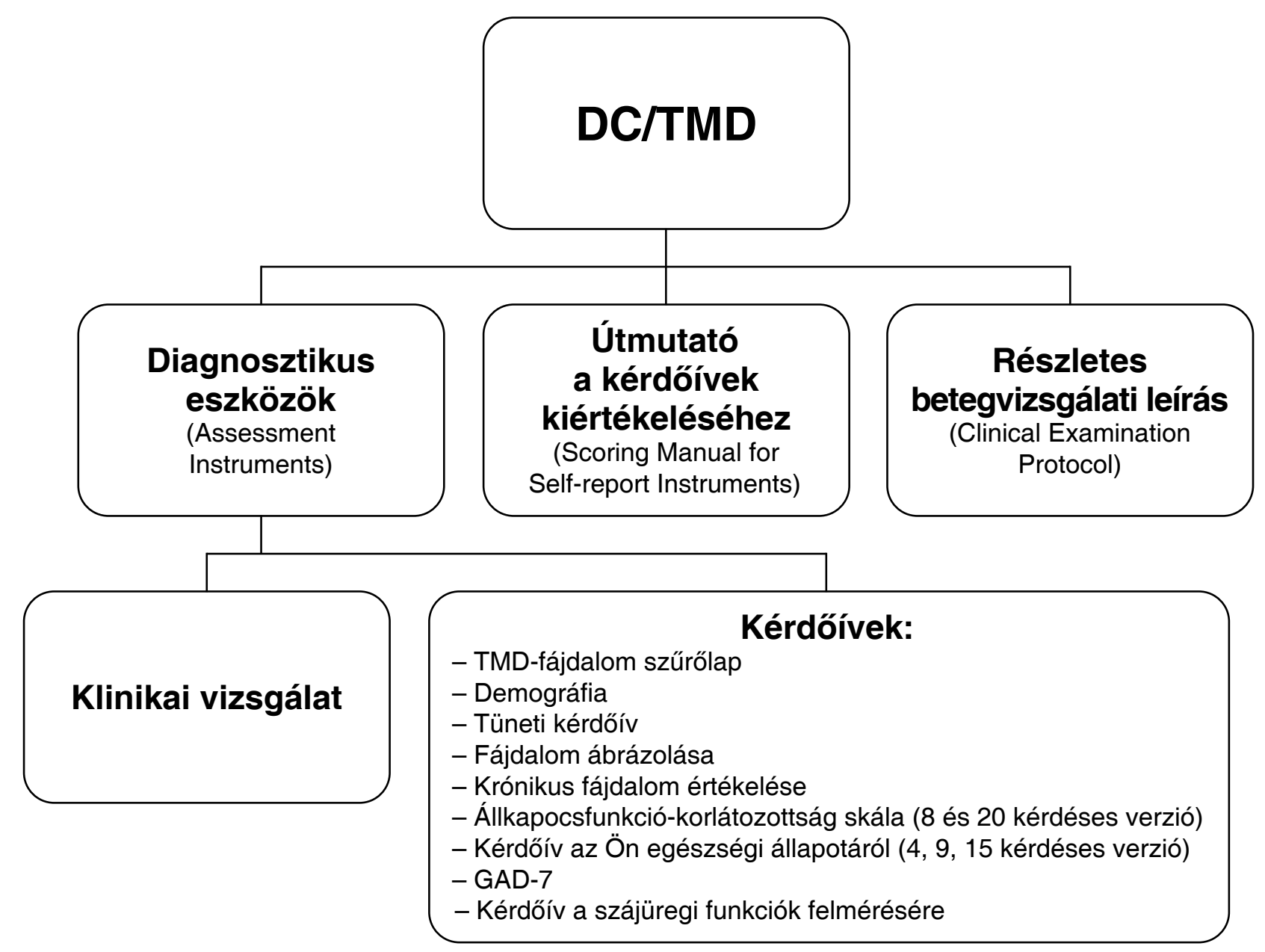

1. ábra: A DC/TMD felépítése

1. Első fordító (magyar anyanyelvü, ismeri a DC/TMD-t): angolról magyarra fordítás

2. Második fordító (magyar anyanyelvű, laikus): angolról magyarra fordítás

3. Visszafordítást végző személy (angol anyanyelvü, magyarul jól beszélö): magyarról angolra fordítás

4. Koordinátor

5. Független fordítás-ellenőrző

6. Klinikus

7. Nyelvész

8. Pszichológus

2. ábra: A magyar változatot létrehozó team összetétele

adaptációs folyamat team-munkát igényel. A magyar változat létrehozásakor a Pécsi Tudományegyetem Általános Orvostudományi Kar Fogászati és Szájsebészeti Klinikán 2015-ben felállt team összetételét és az egyes tagok feladatát a 2 . ábra szemlélteti.

\section{Eredmények}

A teljes DC/TMD rendszer terjedelme miatt azok az elemek kerültek lefordításra, melyeket a pácienseknek kell elolvasni és kitölteni (kérdőívek), illetve a betegvizsgálati utasítások verbális elemei. A lefordított kérdőívek a következők: TMD-fájdalom szürőlap (TMD Pain Screener), Demográfia (Demographics), Tüneti kérdőív (Symptom Questionnaire), Fájdalom ábrázolása (Pain Drawing), Krónikus fájdalom értékelése (GCPS: Graded Chronic Pain Scale), Állkapocs-funkció korlátozottságskála (JFLS: Jaw Functional Limitation Scale, 8 és 20 kérdéses verzió) (3. kép), Kérdőív az Ön egészségi állapotáról (PHQ: Patient Health Questionnaire, 4, 9, 15 kérdéses verzió), GAD-7 (Generalised Anxiety Disorder-7), Kérdőív a szájüregi funkciók felmérésére (Oral Behaviors Checklist). A betegvizsgálati utasítások (Examiner Commands) teljes egészben lefordításra kerültek.

A DC/TMD honosítása két fő fázisból állt: (1) fordítás és kulturális adaptáció, valamint a (2) validálás. A folyamat szekvenciális, ami azt jelenti, hogy az egyes lépések szigorúan egymást követik (3. ábra). A fordítás, visszafordítás, fordítás-ellenőrzés után létrehozott új (magyar) nyelvű változat adaptációja történt az ittho- 


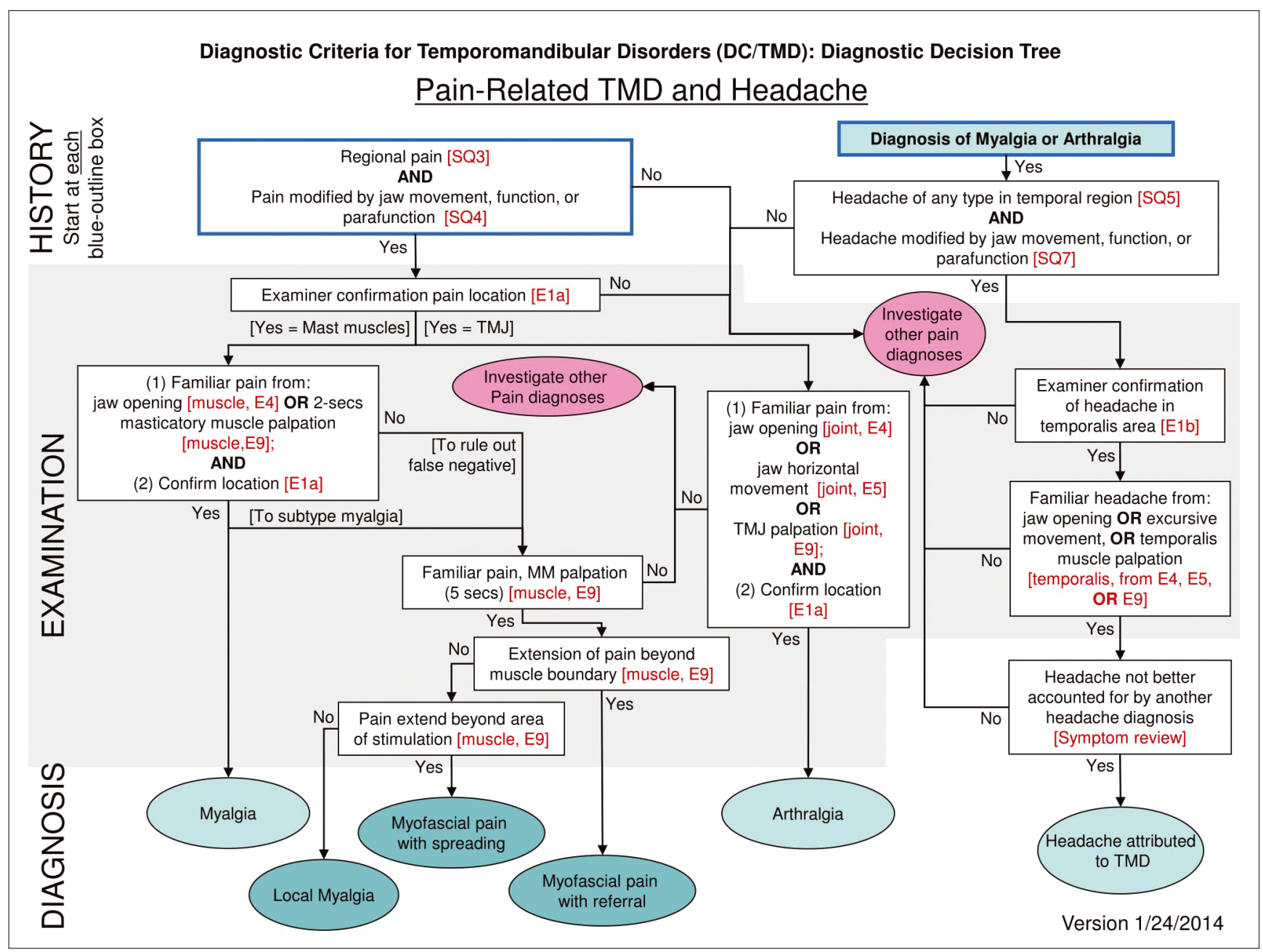

1. kép: I. tengely diagnózisok: fájdalom és fejfájás.

Jelmagyarázat: „SQ” - Symptom Questionnaire (Tüneti Kérdőív), „E” - Examination (Klinikai Vizsgálat),

a számok pedig a kérdések sorszámát jelentik

ni szociális-kulturális környezethez. A rendszert a honosítás első fázisában még nem vetettük alá betegeken történő tesztelésnek, mivel ez majd a validálás része lesz (pre-testing illetve field-testing).

Az első fázis (fordítási-kulturális adaptációs folyamat) közel 2 évet vett igénybe és a DC/TMD magyar változatát 2017 szeptemberében tettük közzé. A rendszer az INfORM honlapján megtalálható és onnan szabadon letölthető [6].

\section{Megbeszélés}

Egy adott populációban megbízhatóan múködő, összetett diagnosztikus rendszernek az átültetése egy másik nyelvi-kulturális közegbe komoly kihívást jelent még az ezen a területen tapasztalt szakemberek számára is. A mi kutatócsoportunk célja az volt, hogy a DC/TMD általunk elkészített magyar változata az eredetivel azonos módon alkalmas legyen a TMD különböző formáinak diagnosztizálására és a rendellenességhez kap- csolódóan a pszichológiai státusz, az orális funkciók és a fájdalom jellegének felmérésére.

A fordítási folyamat során fellépő nehézségek részben nyelvi, részben pedig szociális-kulturális jellegüek voltak. A fordítás során azt a fő szempontot kellett figyelembe vennünk, hogy az eredeti szöveg szándékolt jelentése megmaradjon, ugyanakkor a lefordított rendszer a magyar betegek számára érthető és egyértelmúen értelmezhető legyen. Az ebből fakadó nyelvi kihívások ráadásul különböző természetüek a Betegvizsgálati utasítások verbális utasításaiban és kérdéseiben, valamint a kérdőívek írott szövegében (4. ábra).

Az elkészült magyar DC/TMD nem tekinthető véglegesnek. A honosítás második fázisában a rendszer validálása történik, amikor is először klinikai viszonyok között, pácienseken vizsgáljuk a betegvizsgálati utasítások és kérdőívek használhatóságát (kvalitatív analízis). Amennyiben itt felmerülnek az érthetőséggel vagy egy adott elem relevanciájával kapcsolatos problémák, akkor természetesen lesz lehetőség a kérdéses elem 


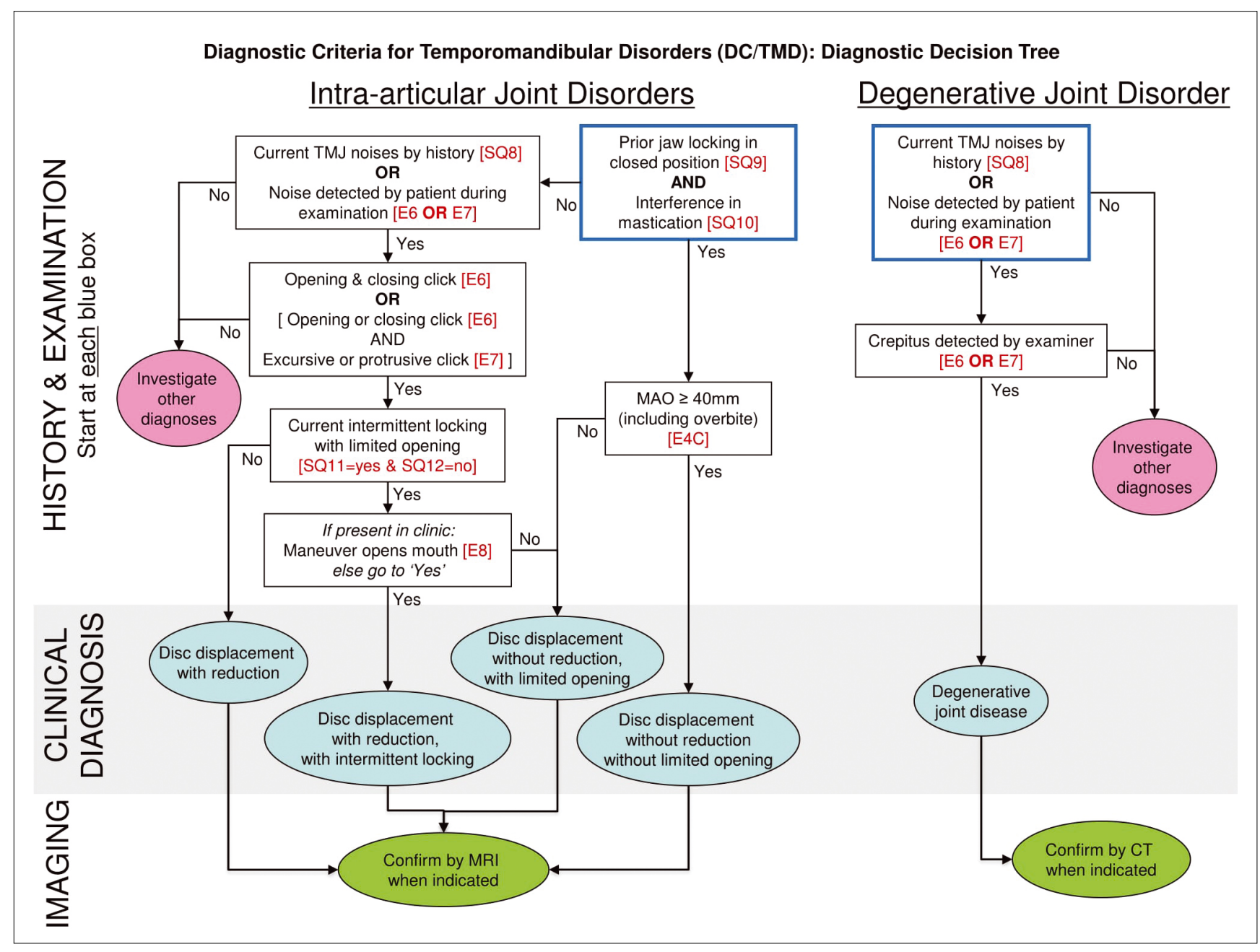

2. kép: I. tengely diagnózisok: intrakapszuláris elváltozások. Jelmagyarázat: „SQ” - Symptom Questionnaire (Tüneti Kérdőív), „E” - Examination (Klinikai Vizsgálat), a számok pedig a kérdések sorszámát jelentik

megváltoztatására, újrafogalmazására, esetleg eltávolítására.

A magyar DC/TMD klinikai és kutatási célokra egyaránt használható. Klinikai alkalmazás esetén az I. tengely diagnózisokon túl lehetőség van a II. tengely egyes elemeinek használatára a vizsgálat szempontjából releváns kérdőívek kiválasztásával (például a terápia során a fájdalom változásának nyomon követése a TMDFájdalom Szürőlap segítségével). Meg kell azonban jegyezni, hogy a rendszer elsősorban szakemberek számára készült és megbízható módon történő használatához feltétlenül szükséges a specifikációk és vizsgálati útmutatások ismerete (például a rágóizmok tapintásakor a megfelelő anatómiai lokalizáció és a tapintáskor használt erő nagyságának pontos kalibrálása).

A DC/TMD rendszer terjedelme miatt csak azon részek/elemek fordítása és adaptációja történt meg, melyek a betegvizsgálathoz és a páciens TMD-vel kapcsolatos állapotának felméréséhez szükségesek. A magyar változat így teljes mértékben használható a diagnózis felállítására a hazai betegeken, ugyanakkor a vizsgá- lati protokoll és az eredményeket értékelő részek angol nyelvűek maradtak. A jövőben lehetőség lesz ezen részek lefordítására is.

Szeretnénk megjegyezni, hogy terveink között szerepel az INfORM-mal együttmüködve egy rövid, kimondottan klinikai célokra alkalmas DC/TMD megalkotása is.

A szerzők köszönetet mondanak Dr. Rébék-Nagy Gábornak (PTE ÁOK Egészségügyi Nyelvi és Kommunikációs Intézet) és Kimberley Daviesnek a fordítási folyamatban nyújtott segítségért.

A DC/TMD magyar változatának elkészítéséhez anyagi támogatást nyújtott a Pécsi Tudományegyetem Klinikai Orvostudományok Doktori Iskolája.

Szerzői munkamegosztás: S. I.: kutatómunka vezetése, kézirat szövegezése, R. A.: kézirat szövegezése, részvétel a kutatásban, N. Á.: kézirat ellenőrzése, szerkesztése, R. M.: kutatás koordinálása, kézirat szerkesztése.

A cikk végleges tartalmát valamennyi szerző elolvasta és jóváhagyta.

A szerzőknek nincsenek érdekeltségeik. 


\section{Állkapocs-funkció Korlátozottság Skála - 20}

Kérjük, jelölje be az alábbi sorok mindegyikénél az elmúlt hónapban tapasztalt nehézség mértékét! Ha az adott tevékenységet teljesen elkerülte, mert túl nehéz volt, akkor a „10”-et karikázza be! Ha nem fájdalom vagy nehézség, hanem más ok miatt kerülte az adott tevékenységet, akkor hagyja a sort üresen!

$\begin{array}{lr}\text { Nincs } & \text { Súlyos } \\ \text { nehézség } & \text { nehézség }\end{array}$

\section{Rágós étel rágása}

$\begin{array}{lllllllllll}0 & 1 & 2 & 3 & 4 & 5 & 6 & 7 & 8 & 9 & 10\end{array}$

2. Kétszersült vagy pirítós kenyér rágása $\quad \begin{array}{lllllllllllll}0 & 1 & 2 & 3 & 4 & 5 & 6 & 7 & 8 & 9 & 10\end{array}$

3. Csirkehús rágása (pl. sütöben készített) $\quad \begin{array}{llllllllllll}0 & 1 & 2 & 3 & 4 & 5 & 6 & 7 & 8 & 9 & 10\end{array}$

$\begin{array}{llllllllllllll}\text { 4. Ropogtatnivaló rágása } & 0 & 1 & 2 & 3 & 4 & 5 & 6 & 7 & 8 & 9 & 10\end{array}$

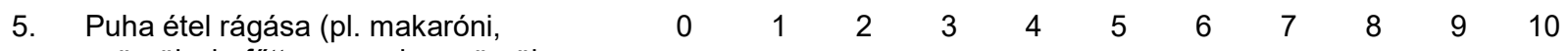
gyümölcsbefött vagy puha gyümölcs, főtt zöldség, hal)

6. Puha, rágást nem igénylő étel fogyasztása (pl. burgonyapüré, almaszósz, puding, pépes étel)

7. Szájnyitás akkorára, hogy egy egész $\quad \begin{array}{lllllllllllll}0 & 0 & 1 & 2 & 3 & 4 & 5 & 6 & 7 & 8 & 9 & 10\end{array}$ almába bele tudott harapni

8. Szájnyitás akkorára, hogy egy $\quad \begin{array}{llllllllllll} & 0 & 1 & 2 & 3 & 4 & 5 & 6 & 7 & 8 & 9 & 10\end{array}$ szendvicsbe bele tudott harapni

9. Szájnyitás akkorára, hogy beszélni $\quad \begin{array}{llllllllllll} & 0 & 1 & 2 & 3 & 4 & 5 & 6 & 7 & 8 & 9 & 10\end{array}$ tudott 10. Szájnyitás akkorára, hogy inni tudott
egy csészéböl

11. Nyelés

12. Ásítás

$\begin{array}{lllllllllll}0 & 1 & 2 & 3 & 4 & 5 & 6 & 7 & 8 & 9 & 10\end{array}$

13. Beszéd

14. Éneklés

15. Vidám arckifejezés

16. Mérges arckifejezés

$\begin{array}{lllllllllll}0 & 1 & 2 & 3 & 4 & 5 & 6 & 7 & 8 & 9 & 10\end{array}$

17. Szemöldök ráncolása

18. Csókolás

$\begin{array}{lllllllllll}0 & 1 & 2 & 3 & 4 & 5 & 6 & 7 & 8 & 9 & 10\end{array}$

19. Mosolygás

20. Nevetés

$\begin{array}{lllllllllll}0 & 1 & 2 & 3 & 4 & 5 & 6 & 7 & 8 & 9 & 10 \\ 0 & 1 & 2 & 3 & 4 & 5 & 6 & 7 & 8 & 9 & 10 \\ 0 & 1 & 2 & 3 & 4 & 5 & 6 & 7 & 8 & 9 & 10 \\ 0 & 1 & 2 & 3 & 4 & 5 & 6 & 7 & 8 & 9 & 10 \\ 0 & 1 & 2 & 3 & 4 & 5 & 6 & 7 & 8 & 9 & 10 \\ 0 & 1 & 2 & 3 & 4 & 5 & 6 & 7 & 8 & 9 & 10 \\ 0 & 1 & 2 & 3 & 4 & 5 & 6 & 7 & 8 & 9 & 10\end{array}$

Copyright Ohrbach R. Translated by Somoskövi I, Radácsi A, Radnai M, all at University of Pécs. Available at http://www.rdc-tmdinternational.org

Version 12May2013. No permission required to reproduce, translate, display, or distribute. 


\section{I. fázis: FORDÍTÁS ÉS KULTURÁLIS ADAPTÁCIÓ}

1. A forrás (angol nyelvű) DC/TMD fordítása magyar nyelvre két fordító által (egy kompetens és egy laikus fordítás)

2. A két fordítás egyesítése egy „közös” magyar verzióvá

3. A magyar verzió visszafordítása angolra

4. A visszafordított rendszer összevetése az eredetivel (egy a rendszert ismerő, független szakértő által)

5. A különbségek felülvizsgálata

6. Egységes, belső ellenőrzésre alkalmas változat elkészítése

7. Szakemberekből álló panel értékelés és kulturális relevancia vizsgálata

8. Végleges formátum elkészítése

9. Adminisztratív ellenőrzés (INfORM által)

10. A DC/TMD magyar változatának közzététele

\section{II. fázis: VALIDÁLÁS ÉS DOKUMENTÁCIÓ}

3. ábra: A DC/TMD honosításának lépései

\section{Irodalom}

1. Cunha SC, Nogueira RVB, Duarte AP, Vasconcelos BCE, Almeida RAC: Analysis of helkimo and craniomandibular indexes for temporomandibular disorder diagnosis on rheumatoid arthritis patients. Rev Bras Otorrinolaringo. 2007: 19-26.

2. Deyo RA, Dworkin SF, Amtmann D, Andersson G, Borenstein D, Carragee E ET al: Report of the NIH task force on research standards for chronic low back pain. Pain Med. 2014: 1249-1267.

3. Dworkin SF, LeResche L: Research diagnostic criteria for temporomandibular disorders: review, criteria, examinations and specifications, critique. J Craniomandib Disord. 1992: 301-355.

4. Horst OV, Cunha-Cruz J, Zhou L, Manning W, Mancl L, DeRouen TA: Prevalence of pain in the orofacial regions in patients visiting general dentists in the Northwest Practice-based Research Collaborative in Evidence-based Dentistry research network. J Am Dent Assoc. 2015: 721-728.

5. https://ubwp.buffalo.edu/rdc-tmdinternational/other-resources/ translation-guidelines/ (2017.11.29.)

6. https://ubwp.buffalo.edu/rdc-tmdinternational/tmd-assessmentdiagnosis/dc-tmd/dc-tmd-translations/ (2017.11.29.)

7. Ohrbach R, Dworkin SF: The Evolution of TMD Diagnosis. J Dent Res. 2016: 1093-1101.

8. Schiffman E, Ohrbach R, Truelove E, Look J, Anderson G, GouLET J-P ET AL: International RDC/TMD Consortium Network, International Association for Dental Research; Orofacial Pain Special Interest Group, International Association for the Study of Pain. Diagnostic Criteria for Temporomandibular Disorders (DC/TMD) for clinical and research applications: recommendations of the International RDC/TMD Consortium Network and Orofacial Pain Special Interest Group. J Oral Fac Pain Headache. 2014: 6-27.

9. Sharma S, Gupta DS, Pal US, Jurel SK: Etiological factors of temporomandibular joint disorders. Natl J Maxillofac Surg 2011: 116-119.

10. Silva CG, Pereira CP, Porporatti AL, Savi MG, Peres Ma, Mir CF CANTO GDL: Prevalence of clinical signs of intra-articular temporomandibular disorders in children and adolescents: A systematic review and meta-analysis. J Am Dent Assoc. 2016: 10-18.

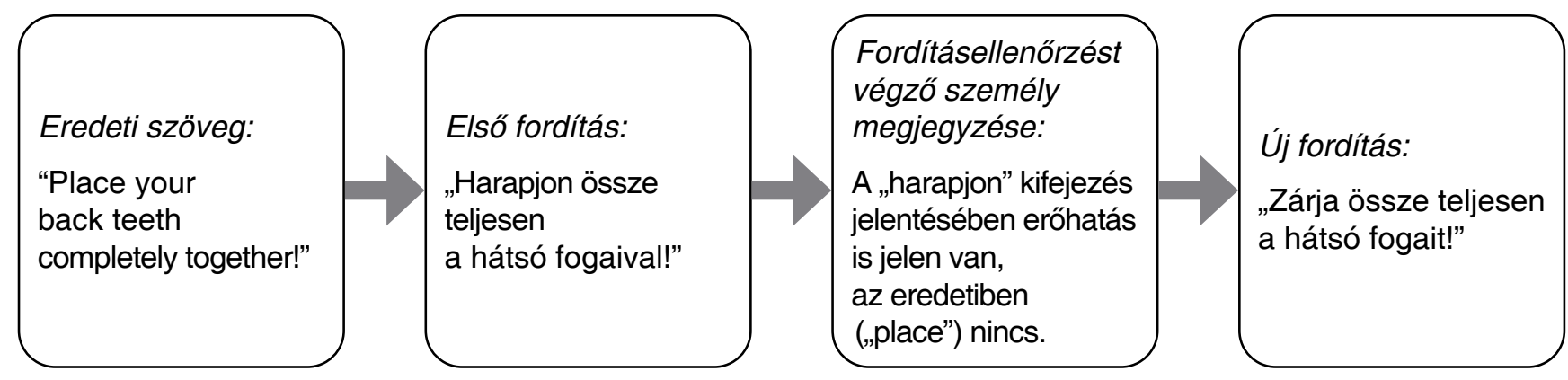

4. ábra: A fordítás során jelentkező nyelvi problémák megoldásának folyamata 


\section{Somoskövi I, RadÁcsı A, Nagy Á, Radnai M}

\section{Developing the Hungarian version of the Diagnostic Criteria for Temporomandibular Disorders (DC/TMD)}

Introduction: Temporomandibular disorders (TMDs) are among the most challenging group of diseases in medicine regarding both their etiology and therapy. The diagnosis of TMD has evolved significantly over the last decades. The Diagnostic Criteria for Temporomandibular Disorders (DC/TMD) was introduced in 2014 by Schiffman et al. The aim of the developers was to create a standardized diagnostic tool intended for use in both clinical and research settings. The DC/TMD has been translated to several languages. The aim of our research team was to develop the Hungarian version.

Materials and methods: Translation and cultural adaptation of DC/TMD is a multistep process that follows the guidelines set up by the International Network for Orofacial Pain and Related Disorders Methodology in order to ensure that the different language versions created are equally useable as the original one.

Results: We started developing the Hungarian version of DC/TMD in 2015 and finalized the translation phase in 2017. After making it available to others, we are planning to start testing the instrument in the Hungarian population.

Discussion: The translation process has been a unique experience for our team which had to face several difficulties during the development. In this article we discuss the process of translation and cultural adaptation. We believe that professionals who work in this field of dentistry can benefit from getting acquainted with the DC/TMD and its benefits in TMD diagnostics.

Keywords: TMD, chronic pain, diagnostic criteria, orofacial pain, translation, cultural adaptation 